Article

\title{
Impacts of Meteorological Factors, VOCs Emissions and Inter-Regional Transport on Summer Ozone Pollution in Yuncheng
}

\author{
Chenyue Zhang ${ }^{1}$, Shuzhen Luo ${ }^{1}$, Wenting Zhao ${ }^{1}$, Yuntao Wang ${ }^{1}$, Qiang Zhang ${ }^{1, *}$, Chengkai Qu ${ }^{2}{ }^{\mathbb{D}}$, \\ Xingang Liu ${ }^{3}$ and Xiaoyu Wen ${ }^{1}$
}

1 College of Urban and Environmental Sciences, Northwest University, Xi'an 710127, China; 201931873@stumail.nwu.edu.cn (C.Z.); 202032560@stumail.nwu.edu.cn (S.L.); 202021008@stumail.nwu.edu.cn (W.Z.); wangyuntao@stumail.nwu.edu.cn (Y.W.); 201931908@stumail.nwu.edu.cn (X.W.)

2 State Key Laboratory of Biogeology and Environmental Geology, China University of Geosciences, Wuhan 430074, China; chengkai.qu@cug.edu.cn

3 State Key Laboratory of Water Environment Simulation, School of Environment, Beijing Normal University, Beijing 100875, China; liuxingang@bnu.edu.cn

* Correspondence: zhang-qiang@nwu.edu.cn; Tel.: +86-18009180696

\section{check for}

updates

Citation: Zhang, C.; Luo, S.; Zhao, W.; Wang, Y.; Zhang, Q.; Qu, C.; Liu, X.; Wen, X. Impacts of Meteorological Factors, VOCs Emissions and Inter-Regional Transport on Summer Ozone Pollution in Yuncheng. Atmosphere 2021, 12, 1661. https://doi.org/ $10.3390 /$ atmos 12121661

Academic Editor: Iustinian Gabriel Bejan

Received: 5 November 2021

Accepted: 9 December 2021

Published: 10 December 2021

Publisher's Note: MDPI stays neutral with regard to jurisdictional claims in published maps and institutional affiliations.

Copyright: (c) 2021 by the authors. Licensee MDPI, Basel, Switzerland. This article is an open access article distributed under the terms and conditions of the Creative Commons Attribution (CC BY) license (https:// creativecommons.org/licenses/by/ $4.0 /)$.
Abstract: Summer ozone $\left(\mathrm{O}_{3}\right)$ pollution in China has become increasingly serious in recent years This study is based on hourly data of near-surface ozone $\left(\mathrm{O}_{3}\right)$ and nitrogen oxides (NOx) and volatile organic compounds (VOCs) from June to August 2020 in Yuncheng, combined with meteorological data to analyse the characteristics of $\mathrm{O}_{3}$ pollution in summer and the influence of meteorological factors, precursors, and long-range transport on $\mathrm{O}_{3}$ pollution. In this paper, the VOCs/NOx characteristic ratio method was used to explore the sensitivity of $\mathrm{O}_{3}$ generation. Backward trajectories, cluster analysis, potential source contribution factor (PSCF) analysis and concentration weight trajectory (CWT) analysis were also calculated using Trajstat software. In 2020, Yuncheng had persistent $\mathrm{O}_{3}$ pollution, with the highest concentrations in June, significantly higher than July and August. Conditions of high temperature, low relative humidity and low wind speed contribute to the $\mathrm{O}_{3}$ accumulation. VOCs are the main precursors to the local production of $\mathrm{O}_{3}$. Besides, the long-range transport analysis shows that southeast-oriented air masses are the main direction influencing summer $\mathrm{O}_{3}$ pollution. The primary potential source areas of $\mathrm{O}_{3}$ are in the central and southern part of Henan province, the north-western Anhui province, and the northern Shaanxi. In addition, northern Hubei and southwestern Shandong also influence $\mathrm{O}_{3}$ pollution in summer Yuncheng.

Keywords: ozone formation; meteorological factors; characteristic ratio method; Hysplit model; Trajstat software

\section{Introduction}

After implementing the Chinese government's air pollution prevention and control plan, China has achieved remarkable achievement for the frequent $\mathrm{PM}_{2.5}$ pollution in heating seasons [1,2]. However, tropospheric ozone $\left(\mathrm{O}_{3}\right)$ pollution in summer has increased year by year $[3,4]$. According to statistics, $\mathrm{O}_{3}$ concentrations in key cities in mainland China increased year by year after 2013, with the most pronounced increase in the Beijing-Tianjin-Hebei Region (BTH), Yangtze River Delta (YRD) and Pearl River Delta (PRD) regions [5]. $\mathrm{O}_{3}$ concentrations across Eastern China increased by about $10 \%$ in recent years [6]. Therefore, near-surface $\mathrm{O}_{3}$ concentrations are a critical factor influencing summer air quality in China.

Near-surface $\mathrm{O}_{3}$ is a typical secondary pollutant, and its primary source is the photochemical reaction of atmospheric volatile organic compounds (VOCs) and nitrogen oxides (NOx) under solar radiation conditions [7]. Although the stratosphere may transport some $\mathrm{O}_{3}$ to the troposphere, the concentration is only $1 / 15$ to $1 / 7$ of the $\mathrm{O}_{3}$ produced by photochemical reactions [8]. At the same time, $\mathrm{O}_{3}$ pollution tends to occur more readily during 
the summer months with high temperatures, intense solar radiation, low wind speed and low humidity [9]. Many related studies have discussed the causes of $\mathrm{O}_{3}$ contamination and found that the high concentration events are a combination of adverse meteorological conditions, precursor emissions and long-range transportation [10-12].

Sensitivity determination of $\mathrm{O}_{3}$ precursors using the VOCs/NOx characteristic ratio method is one of the most important qualitative methods for determining control factors of $\mathrm{O}_{3}$ production in an area. It is generally accepted that $\mathrm{O}_{3}$ is in the NOx-limited regime when the VOCs/NOx ratio is higher than 8 , and the concentration of NOx directly affects the $\mathrm{O}_{3}$ pollution level. When VOCs/NOx $<4$, which indicates that the $\mathrm{O}_{3}$ generation mechanism is in the VOCs-limited regime $[13,14]$, and that the magnitude of VOCs concentration becomes the primary control factor of $\mathrm{O}_{3}$ pollution. When the VOCs/NOx concentration is in the range of $4-8$, it is still in the VOCs-limited regime. However, NO reduction has an adverse effect $[15,16]$ because the decrease in $\mathrm{NOx}$ concentrations will increase $\mathrm{O}_{3}$ pollution levels instead.

This paper chooses Yuncheng as the study area (Figure 1), a typical city in the Fenwei Plain, because the intensive heavy industry, extensive solid fuels usage, and road traffic structure cause severe air pollution [17]. Yuncheng is located in the core of the Fenwei Plain and is in the pollution transmission zone of the Xi'an-Linfen impact plain, so the air quality condition of Yuncheng has a significant influence on the surrounding cities [18,19]. Currently, most of the near-surface $\mathrm{O}_{3}$ pollution research focus on economically developed areas of China, such as Beijing [20], YRD [21], and PRD [22]. There is a lack of studies in small or medium-sized cities on the pollution characteristics, influencing factors, precursors analysis and potential long-distance source regions of $\mathrm{O}_{3}$ contamination.

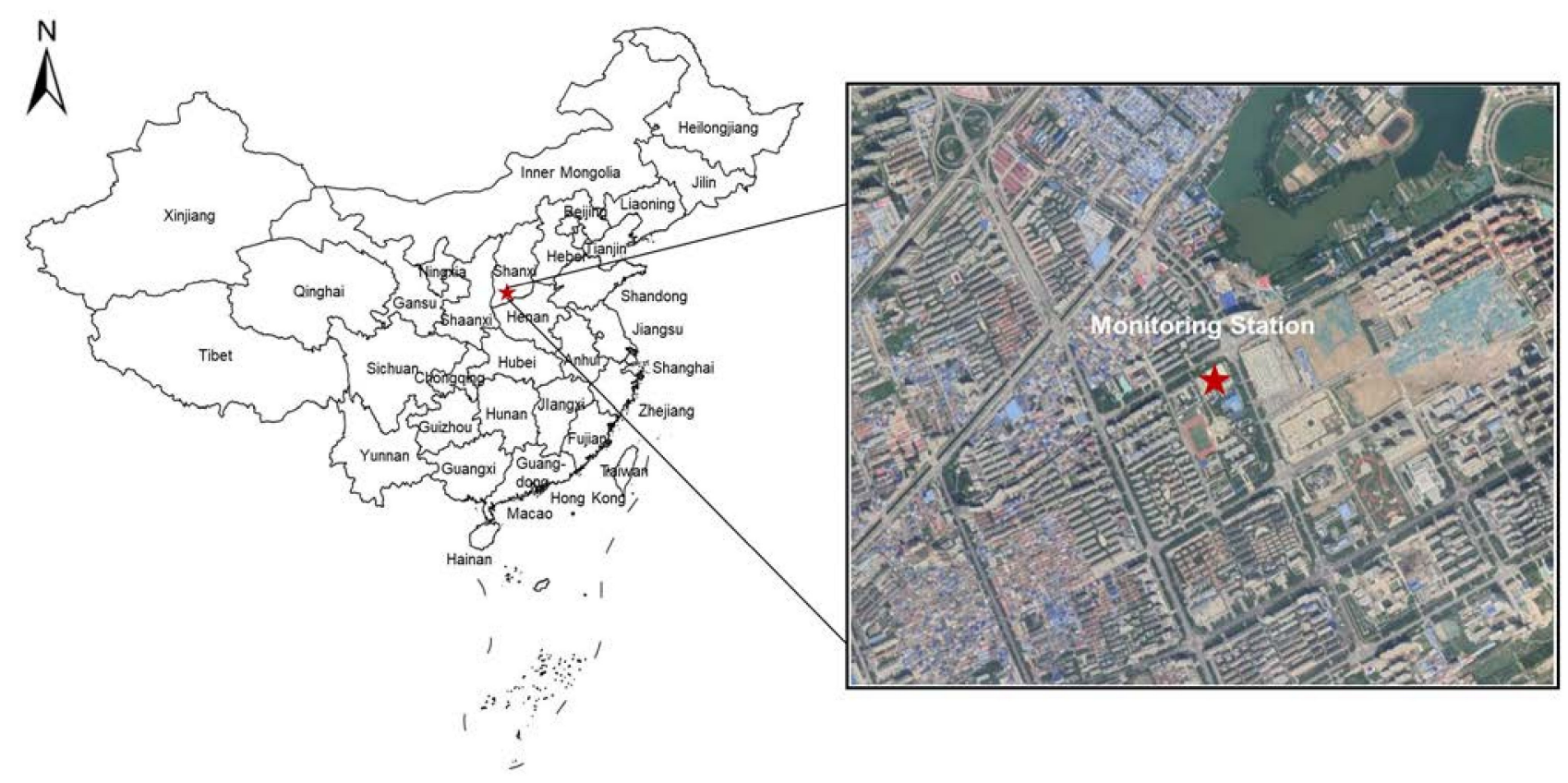

Figure 1. Map of China's administrative divisions and the location of the monitoring site.

Hourly $\mathrm{O}_{3}$ concentration monitoring data from June to August 2020 are the primary data used in this research. This paper includes four parts: (1) analysed $\mathrm{O}_{3}$ and its precursors' pollution characteristics, (2) showed the influences of meteorological factors on $\mathrm{O}_{3}$ concentration, (3) analysed the relationship between precursors and $\mathrm{O}_{3}$ production by using the characteristic ratio method (VOCs/NOx), (4) using potential source contribution factor (PSCF) analysis and concentration weight trajectory (CWT) analysis provided by Trajstat software to study the regional transport characteristics of $\mathrm{O}_{3}$ and its potential source areas in different seasons in Yuncheng City. It is expected to provide a scientific reference 
basis for $\mathrm{O}_{3}$ pollution control and emission reduction policy formulation in Yuncheng City and other urban clusters in the Fenwei Plain.

\section{Data and Methods}

\subsection{Study Area and Data Sources}

\subsubsection{Overview of the Study Area}

The city of Yuncheng $\left(110.98^{\circ} \mathrm{E}, 35.02^{\circ} \mathrm{N}\right)$ is in the southwestern part of Shanxi province, surrounded by the Luliang mountains, Zhongtiao mountains and Yellow River, respectively. The topography of Yuncheng is dominated by low mountains, hills, plains and Chinese Loess Plateau. The climate is warm-temperate continental monsoon with cold and dry winters, hot and rainy summers, with an average annual temperature and rainfall of $13{ }^{\circ} \mathrm{C}$ and $537 \mathrm{~mm}$, respectively. Nearly half of the rain concentrated from July to September [23].

\subsubsection{Data Sources}

$\mathrm{O}_{3}$ and NOx concentration data and meteorological data (temperature, wind speed, wind direction, relative humidity) for Yuncheng from 1 January 2018 to 31 December 2020 can be obtained from the National Air Quality Networked Monitoring Management Platform at hourly resolution.

The meteorological fields data used in the backward trajectory model (HYSPLIT) came from the Global Data Assimilation System (GDAS), which was provided by the National Centers for Environmental Prediction (NCEP) (ftp:/ /arlftp.arlhq.noaa.gov/pub/archives/gdas1, access on 30 October 2021). The GDAS database provides daily statistics at 00:00, 06:00, 12:00, 18:00 (UTC) with a spatial resolution of $1^{\circ} \times 1^{\circ}$.

The monitoring station for this study was the roof of Yuncheng Middle School, Yanhu District, Yuncheng City, Shanxi Province ( $35.038^{\circ} \mathrm{N}, 111.029^{\circ}$ E). The monitoring site is surrounded by mainly residential and commercial areas and is close to the main traffic roads, a typical urban area. The operational heights of the monitoring points for $\mathrm{O}_{3}$ and NOx are selected according to the technical regulation for selection of ambient air quality monitoring stations (HJ 664-2013) for automatic monitoring equipment. The specification states that if the average height of buildings within a radius of 300-500 $\mathrm{m}$ around the selected point is above $20 \mathrm{~m}$, the height of the sampling port or monitoring beam above the ground should be set within the range of $15-25 \mathrm{~m}$ [24]. Since the building near this sampling point is seven storeys $(>20 \mathrm{~m})$ in height, the selected point in this study is at the top of Yuncheng Middle School, with a height of $23 \mathrm{~m}$ from the ground. The sampling ports of the monitoring instruments are all greater than $1 \mathrm{~m}$ away from the surface of the building walls, roofs, and other supports.

The analysers used for the $\mathrm{O}_{3}$ and NOx observations were manufactured by Thermo Fisher, a US-based thermoelectric environmental instrument company. $\mathrm{O}_{3}$ concentrations were measured using a Model $49 \mathrm{i}_{3}$ analyser with a UV absorption method. This instrument first uses a pump to draw ambient air into the absorption cell. The reaction cell is then irradiated with UV light at a wavelength of $254 \mathrm{~nm}$. The detector will monitor the unabsorbed light passing through the unit, and the Beer-Lambert equation and output will calculate the $\mathrm{O}_{3}$ concentration through the screen. NOx concentrations are measured using the chemiluminescence-based Model 42i NOx analyser. Ambient air enters the system via a pump and dryer unit and is split into two streams. The NO in the first stream reacts with $\mathrm{O}_{3}$ to form active $\mathrm{NO}_{2}$, which quickly changes from an excited state to a ground state and emits a photon. The released photon results from the chemiluminescent radiation, which depends on the amount of NO in the air. Finally, radiated photons are detected using a photomultiplier or photodiode, which outputs voltages of different intensities. The $\mathrm{NO}_{2}$ in the second gas stream can be reduced to $\mathrm{NO}$, and then the sum of the $\mathrm{NO}$ and $\mathrm{NO}_{2}$ concentrations are measured according to the above principle to obtain the NOx concentration. According to G. Villena et al., the concentration of NOx measured by chemiluminescence in urban areas is higher than other methods [25]. However, this study focuses on the effect 
of NOx trends on $\mathrm{O}_{3}$ formation and pays no attention to the NOx's concentration changes. Therefore, this error has little influence on the results of the study.

This study uses a Wuhan Tianhong TH-300B atmospheric VOC online monitoring system to observe VOCs in the environment, mainly consisting of an ultra-low temperature online pre-concentrator and a GC-MS/FID detector. After the atmospheric samples have been collected and entered the ultra-low temperature online pre-concentrator, the VOCs in the environment are frozen and trapped in a capillary trap column. When rapid thermal desorption by the system, they enter the GC-MS analysis system. The components from $\mathrm{C}_{2}$ to $\mathrm{C}_{5}$ are detected in the FID detector, while the MS detects the remaining ingredients. In order to ensure the observation accuracy, aldehydes and ketones, PAMS, TO-15 and internal standards were used in the monitoring process. The three standard gases, aldehydes and ketones, PAMS and TO-15, are certified as BW with an uncertainty of $5 \%$. In contrast, the typical internal gas is licensed as GBWE and contains four substances, namely chlorobromomethane, chlorobenzene-d5, 4-bromofluorobenzene and 1,4-difluorobenzene. The standard gases are diluted and calibrated using zero gas (de-hydrocarbonized air) and the responding standard gas without humidification during dilution. It is worth noting that the standard gas used in the VOCs online monitoring process is non-humid. However, the air compressor draws the carrier gas directly from the atmosphere, so the mixed standard and carrier gases will be humid. This measurement process will essentially have no significant effect on the VOCs monitoring values. Six concentration points $(0.5,2$, $4,6,8$ and $10 \mu \mathrm{g} \cdot \mathrm{L}^{-1}$ ) were set up for multi-point calibration. At least five concentration points were fitted to verify that the correlation coefficient of the target compounds at the time of calibration was 0.98 or higher. Besides, single-point calibration was performed daily using standard gases so that more than $80 \%$ of the target compounds had a concentration deviation of less than $30 \%$ and no more than five key compounds failed. A weekly blank check with zero gas ensured that the monitoring system was not contaminated and that the blank met the target compound concentration of less than $0.1 \mu \mathrm{g} \cdot \mathrm{L}^{-1}$. During the observation period, 68 VOCs were detected, including 29 alkanes, 10 olefins, 1 alkyne, 16 aromatic hydrocarbons and 12 oxygenated volatile organic compounds (OVOCs).

\subsection{Hysplit Model}

The Hysplit model, developed jointly by the National Oceanic Atmospheric Administration (NOAA) and the Australian Bureau of Meteorology, can be used to calculate and analyse airflow movement, deposition and dispersion [26,27]. It is also often used by researchers in air pollution to analyse long-range emission sources and transport analysis of different types of pollutants.

The backward trajectory of Yuncheng City, cluster analysis, PSCF and CWT analysis were all calculated based on Trajstat software [27]. The researcher set the starting point and the height of the simulation as the centre of Yuncheng city $\left(110.98^{\circ} \mathrm{E}, 35.02^{\circ} \mathrm{N}\right)$ and $500 \mathrm{~m}$, respectively, because this height can reflect the inter-regional transportation flow characteristics and reduces the influence of near-surface friction [28]. The duration of the simulation for this study was $48 \mathrm{~h}$. Trajectories began at four times (00:00, 06:00, 12:00, 18:00, UTC). The clustering is based on the angle distance algorithm [29] and the mutation points total spatial variance (TSV) [26].

\subsubsection{Potential Source Contribution Factor Analysis (PSCF)}

The PSCF is based on the HYSPLIT backward trajectory endpoint of the receptor model, which can identify potential sources of atmospheric pollutants using spatial grid probability calculations $[30,31]$. This study divided the research area into $0.5^{\circ} \times 0.5^{\circ}$ grids, and the pollution threshold of $\mathrm{O}_{3}$ is set as $144 \mu \mathrm{g} \cdot \mathrm{m}^{-3}$ (the 75th percentile of the daily average concentration from June to August in 2020) [32]. Pollution thresholds can help 
define pollution trajectories. When a trajectory corresponding concentration is higher than this value, it is a contaminated transport trajectory.

$$
P S C F_{i j}=\frac{m_{i j}}{n_{i j}}
$$

where, "ij" represents the specific location of each grid, " $m_{i j}$ " shows the number of contaminated trajectory endpoints passing through grid " $i j$ ", " $n_{i j}$ " means the endpoints amounts of all trajectories passing through grid " $i j$ ". According to the calculation process of PSCF, when the total number of endpoints $\left(n_{i j}\right)$ of the trajectory in the grid is relatively small, the calculation result may have considerable uncertainty. Therefore, this paper uses a weighting factor $\left(W_{i j}\right)$ to enhance its statistical balance and reduce the error [33].

$$
\begin{gathered}
W_{i j}= \begin{cases}1.0 & n_{i j}>2 \text { avg } \\
0.75 & \text { avg }<n_{i j} \leq 2 \text { avg } \\
0.5 & 0.5 \text { avg }<n_{i j} \leq a v g \\
0.15 & 0<n_{i j} \leq 0.5 \text { avg }\end{cases} \\
\\
\text { WPSCF }_{i j}=W_{i j} \times P S C F_{i j}
\end{gathered}
$$

where, "avg" represents the average number of endpoints of all grids in the study area, " $W_{i j}$ " is the weighting factor, "WPSCF $F_{i j}$ " is the calculation result of the PSCF by " $W_{i j}$ " equilibrium.

\subsubsection{Concentration Weighted Trajectory Analysis (CWT)}

Since the PSCF calculation is based on the ratio of the number of contaminated trajectories passing through a grid to the number of endpoints in a whole way, it is possible that when the concentration is a medium to high strength source, the cells that pass through will have the same calculation result $[34,35]$. CWT is a gridded result of pollution sources obtained by back-projecting using local pollution concentration data combined with air mass trajectories. CWT can be weighted by trajectory residence time and pollutant concentration, taking into account the concentration of pollutants crossing that grid cell and weighting the concentration by residence time [36]. Therefore, CWT can calculate relatively accurate weights for each grid cell traversed at medium and high concentrations, improving the accuracy of the analysis results. Because CWT and PSCF can compensate for shortcomings, researchers always combine the two techniques to identify the source area $[34,37]$.

$$
C W T_{i j}=\frac{1}{\sum_{l=1}^{M} \tau_{i j l}} \sum_{l=1}^{M} C_{l} \tau_{i j l}
$$

where, " $i j$ " represents the specific location of each grid, " $l$ " means a particular transportation trajectory, " $\tau_{i j l}$ " is the residence time of trajectory " $l$ " in grid " $i j$ " (or the number of trajectory endpoints), " $C_{l}$ " is the concentration of $\mathrm{O}_{3}$ as trajectory " $l$ " passes through grid " $i j$ ".To reduce errors, CWT also applies the weighting factor " $W_{i j}$ " quoted by PSCF:

$$
W C W T_{i j}=W_{i j} \times C W T_{i j}
$$

\section{Results and Discussion}

\subsection{Pollution Characteristics of Ozone and Its Precursors}

3.1.1. Ozone Pollution Occurred in Summer 2020

As shown in Figure 2, the time series of $\mathrm{O}_{3}$ hourly pollution levels in Yuncheng from 2018 to 2020 are divided into five classes according to the $\mathrm{O}_{3}$ monitoring concentration values, reflecting the degree of exceedance of the hourly $\mathrm{O}_{3}$ standard $\left(>160 \mu \mathrm{g} \cdot \mathrm{m}^{-3}\right)$ in each month [38]: excellent $\left(0-100 \mu \mathrm{g} \cdot \mathrm{m}^{-3}\right)$, good $\left(100-160 \mu \mathrm{g} \cdot \mathrm{m}^{-3}\right)$, mild pollution $\left(160-215 \mu \mathrm{g} \cdot \mathrm{m}^{-3}\right)$, moderate pollution $\left(215-265 \mu \mathrm{g} \cdot \mathrm{m}^{-3}\right)$ and heavily pollution $\left(265-500 \mu \mathrm{g} \cdot \mathrm{m}^{-3}\right)$ [11]. Yuncheng has experienced varying $\mathrm{O}_{3}$ exceedances from March to September over three consecutive years, predominating mild and moderate pollution. The 
higher levels of pollution are usually in the months of June to August each year, during which there are several consecutive hours of monthly average concentrations reaching moderate pollution. Although the $\mathrm{O}_{3}$ concentration exceedances proportion in 2020 is smaller than in 2019, the pollution characteristics of $\mathrm{O}_{3}$ are more pronounced in the summer of 2020. Not only did hourly concentrations of heavy pollution occur during the night of June, but moderate pollution also occurred more frequently and continuously. Therefore, 2020 was chosen as the base year to identify and analyse local $\mathrm{O}_{3}$ generation factors and potential source areas.

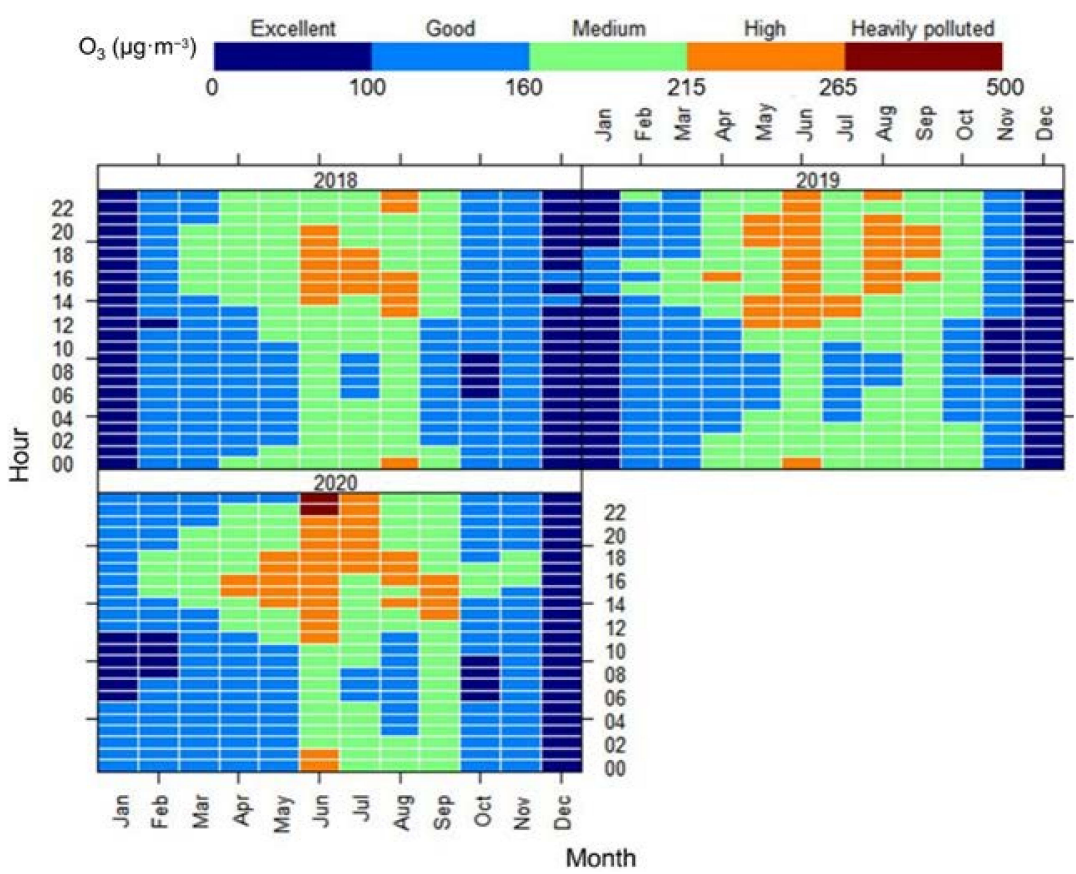

Figure 2. Hourly averages ozone concentration levels over months for 2018-2020 in Yuncheng.

\subsubsection{Opposite Changes in Ozone and Its Precursors}

Both $\mathrm{O}_{3}$ and its precursors show an apparent seasonal or monthly variation. As can be seen from Figure 3, $\mathrm{O}_{3}$ concentrations in 2020 show a clear seasonal pattern of summer $>$ autumn $>$ spring $>$ winter, which is very similar to its pollution situation in many countries and regions in the northern hemisphere $[39,40]$. Because $\mathrm{O}_{3}$ is a photochemical product, intense solar radiation in the northern hemisphere summer is favourable for $\mathrm{O}_{3}$ production [41]. Therefore, ozone concentrations tend to reach higher values more easily from June to August. At the same time, $\mathrm{O}_{3}$ in Yuncheng showed two distinct pollution peaks in 2020, in June and September, with higher pollution levels in June than in September. The decrease in $\mathrm{O}_{3}$ concentrations in July and August may be due to the increase in air humidity, leading to a weakening of solar radiation intensity and thus photochemical reactions. The relationship between $\mathrm{O}_{3}$ concentration and $\mathrm{RH}$ will be discussed in Section 3.2.

The NOx and VOCs concentrations variation are the opposite of $\mathrm{O}_{3}$, showing a high winter and low summer pattern. During the Chinese heating period in winter, continuous heating requires consuming large amounts of solid fuels, which emit more NOx, toluene, and benzene. At the same time, the increased hours of indoor activities of people and the high frequency of private car use also emit more NOx and VOCs [42,43]. Ethane, propane, $\mathrm{n}$-butane, iso-butane, n-pentane, iso-pentane and a proportion of olefins and benzene can be emitted from transportation. From winter to summer, as the weather warms and solar radiation increases, some of the NOx and VOCs are consumed in the photochemical reactions, resulting in a gradual decrease in their concentrations. Therefore, the variation in NOx and VOCs concentrations is closely related to climatic conditions and emission patterns. 


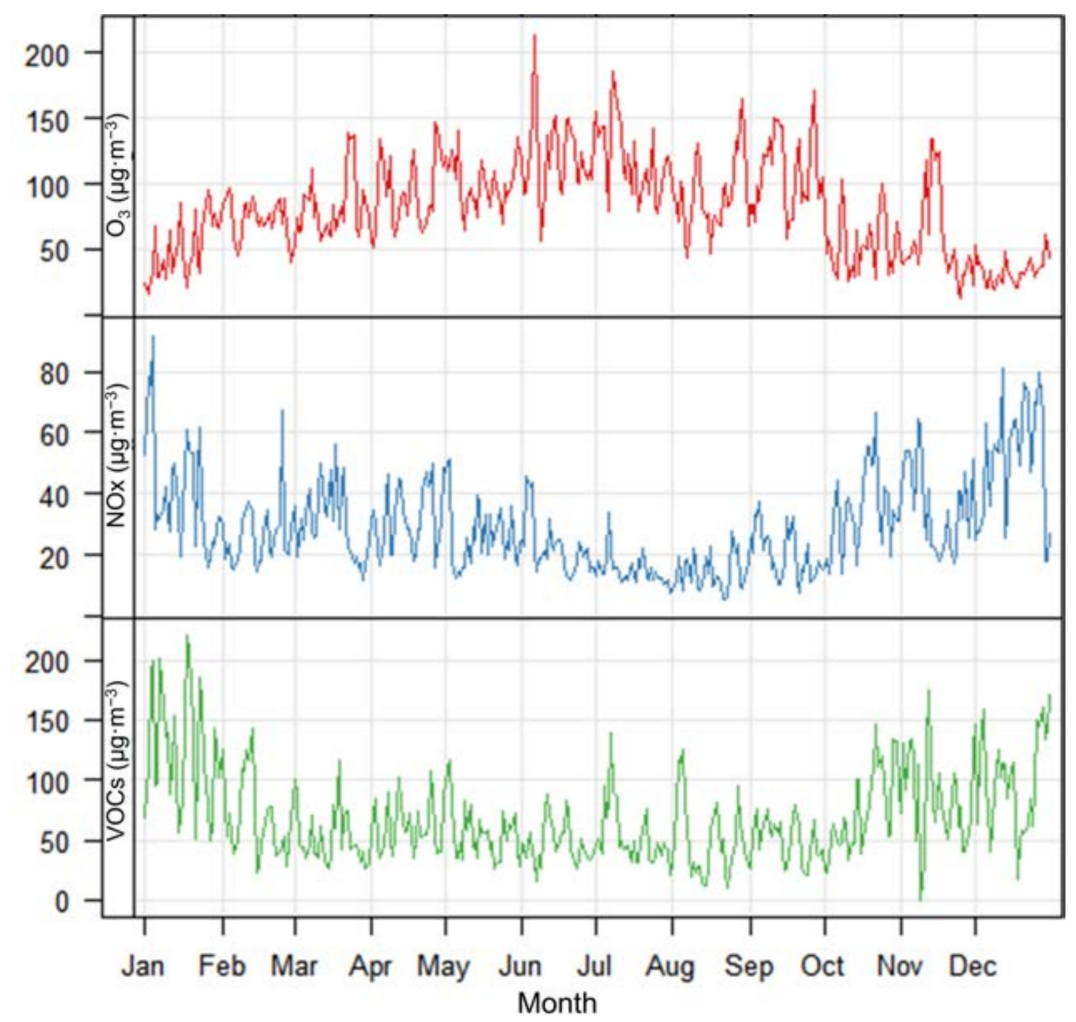

Figure 3. Changes in daily average concentrations of ozone and its main precursors in 2020, Yuncheng. The red, blue, and green dashes represent the change in concentration of $\mathrm{O}_{3}, \mathrm{NOx}$ and VOCs, respectively.

In addition to the effect of VOCs emissions from anthropogenic sources on $\mathrm{O}_{3}$ concentrations, emissions from plant sources in summer may also influence $\mathrm{O}_{3}$ production. The main VOCs that can represent natural sources are isoprene [44]. The contribution of isoprene to VOC concentrations in June, July and August was calculated to be $2.38 \%$, $2.32 \%$ and $1.11 \%$, respectively. Because the monitoring station represents the Yuncheng downtown's pollutants concentration, the influence of biogenic VOCs is much smaller than the emissions from the anthropogenic sources. Therefore, this study mainly focuses on the impact of VOCs generated during anthropogenic activities on $\mathrm{O}_{3}$ in summer in Yuncheng City.

\subsection{The Influence of Meteorological Factors on Ozone Pollution}

Figure 4 uses monthly average hourly data to show the daily trend between $\mathrm{O}_{3}$ concentrations and temperature $\left(\mathrm{Temp},{ }^{\circ} \mathrm{C}\right)$, relative humidity $(\mathrm{RH}, \%)$ and wind speed (WS, m/s) for June to August 2020. $\mathrm{O}_{3}$ concentrations show a positive correlation with temperature throughout June, which means that $\mathrm{O}_{3}$ concentrations increase with climbing air temperature. Solar radiation is the main factor that reflects the intensity of $\mathrm{O}_{3}$ photochemical reactions. In hotter weather, stronger solar radiation tends to occur, so the air temperature level can also show whether the photochemical reactions that generate $\mathrm{O}_{3}$ arise at a given time of year [45]. Therefore, high temperatures in summer promote the occurrence of photochemical reactions of $\mathrm{O}_{3} . \mathrm{O}_{3}$ contamination showed a continuous peak of approximately $150 \mu \mathrm{g} \cdot \mathrm{m}^{-3}$ from 14:00 to 17:00. In addition, the $\mathrm{RH}$ can also determine the strength of the photochemical reaction of $\mathrm{O}_{3}$ [46]. Studies have shown that the intensity of the photochemical reaction reaches a critical value when the $\mathrm{RH}$ is $60 \%$. When $\mathrm{RH}$ is above $60 \%$, there is a decrease in $\mathrm{O}_{3}$ concentration because cloudy weather tends to occur when $\mathrm{RH}$ is high, declining the solar radiation intensity and thus leading to lower $\mathrm{O}_{3}$ concentrations [45]. The $\mathrm{RH}$ can reach around $59 \%$ in the early morning of June in Yuncheng when $\mathrm{O}_{3}$ concentration was less than $100 \mu \mathrm{g} \cdot \mathrm{m}^{-3}$, and at the moment of peak $\mathrm{O}_{3}$ concentrations in the afternoon, the $\mathrm{RH}$ was less than $53 \%$. 


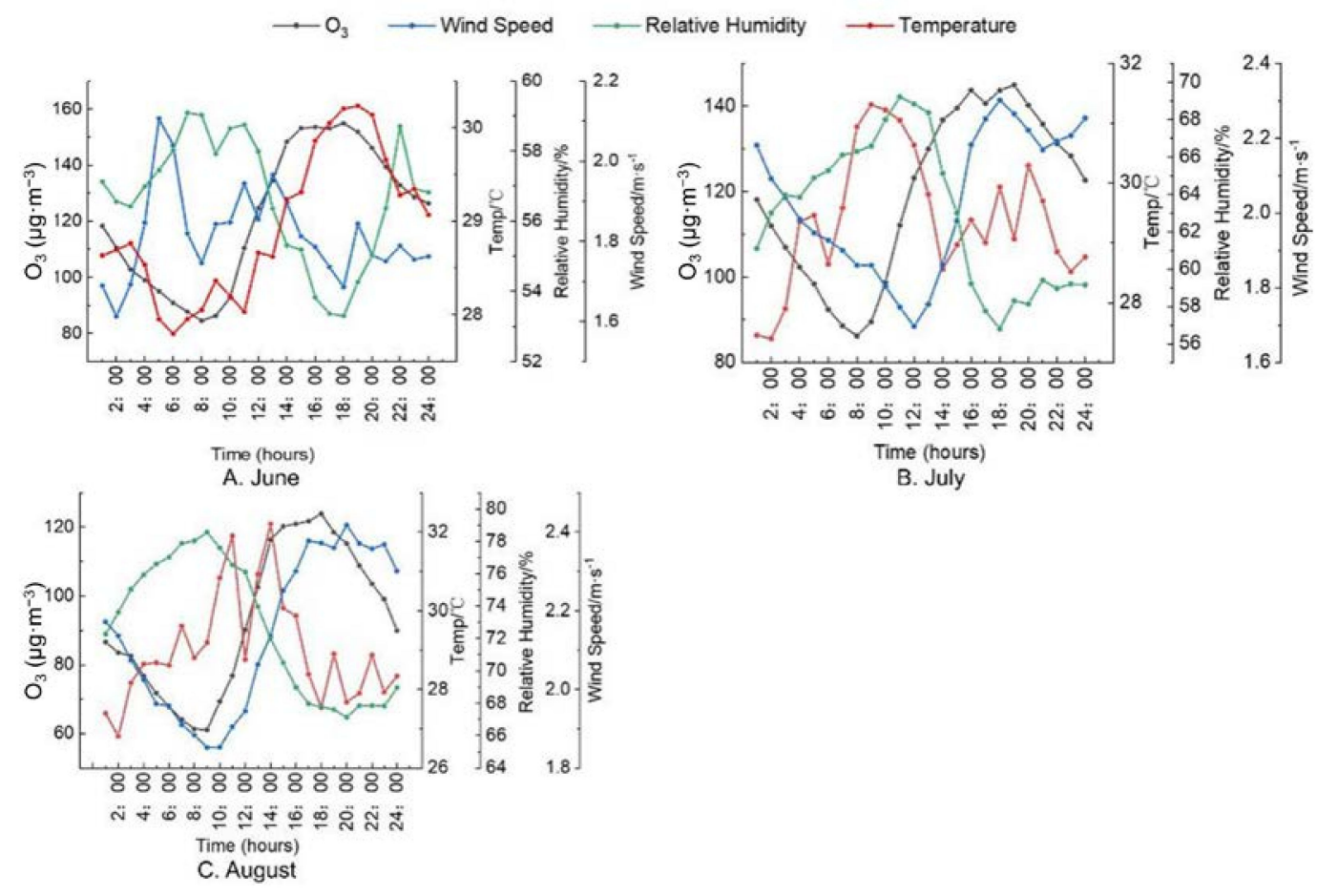

Figure 4. Hourly average values by month changes in ozone concentration, temperature $\left({ }^{\circ} \mathrm{C}\right)$, relative humidity, and wind speed in summer 2020. Subfigure (A-C) represent the weather conditions in June, July, and August.

This phenomenon indicates that the effect of $\mathrm{RH}$ on $\mathrm{O}_{3}$ concentrations is significant. Besides, the short-range transport degree of $\mathrm{O}_{3}$ is influenced by the magnitude of WS, which can also lead to $\mathrm{O}_{3}$ concentrations fluctuations. If under static WS conditions, poorer dispersion conditions for $\mathrm{O}_{3}$ can lead to a concentration accumulating [47]. At 4:00 in the early morning, there was a significant peak in WS in June, which was about $0.3 \mathrm{~m} / \mathrm{s}$ higher than other times, so that $\mathrm{O}_{3}$ concentrations decreased rapidly from $105 \mu \mathrm{g} \cdot \mathrm{m}^{-3}$ to $82 \mu \mathrm{g} \cdot \mathrm{m}^{-3} \cdot \mathrm{O}_{3}$ would diffuse downwind with the near-surface wind, thus reducing the local $\mathrm{O}_{3}$ pollution level to some extent. However, it is worth noting that, although the increase in wind speed helped to improve diffusion conditions, the eventual decrease in $\mathrm{O}_{3}$ concentrations was due to the depletion of $\mathrm{O}_{3}$ by $\mathrm{NO}$ titration at night.

The temperature, RH and WS change trends in July were very different in Yuncheng. Firstly, the peak temperature occurred between 8:00 and 9:00, after which it gradually dropped to around $29^{\circ} \mathrm{C}$ and fluctuated up and down. The reason that temperature cannot reach higher values in the afternoon may be due to the influence of RH. The peak RH $(70 \%)$ appeared around 10:00, with a high temperature. Later, the RH dropped rapidly to around $58 \%$ and remains stable. This is probably because rainy and humid weather tends to occur in the morning when the overall summer temperatures are high, and evaporation absorbs heat, resulting in a rapid drop in $\mathrm{RH}$ and a decrease in temperature. Therefore, the $\mathrm{O}_{3}$ concentrations were low in the early morning $\left(<100 \mu \mathrm{g} \cdot \mathrm{m}^{-3}\right)$ due to high humidity and low temperatures and gradually increased to $140 \mu \mathrm{g} \cdot \mathrm{m}^{-3}$ as the RH decreased rapidly. The overall $\mathrm{O}_{3}$ concentrations are lower in July than in June. The main reason is that, during the time between 14:00 and 15:00, when solar radiation is most robust, temperatures remain relatively low, and dispersion conditions $(2.2 \mathrm{~m} / \mathrm{s})$ are favourable for downwind dispersion.

Similar to the meteorological conditions in July, the RH in August continues to show a "single valley" pattern. The RH peak occurred at 8:00 and can reach around $78 \%$. The troughs appeared after 16:00, but were still above 67\%. The temperature in August peaks at midday and then drops as the $\mathrm{RH}$ drops and eventually remains stable $\left(28{ }^{\circ} \mathrm{C}\right)$. Compared to July, the RH and WS were higher in August, while the temperature did not reach the same level as in July, resulting in a decrease in peak $\mathrm{O}_{3}$ concentrations to around $120 \mu \mathrm{g} \cdot \mathrm{m}^{-3}$. 
The meteorological factors' influences on $\mathrm{O}_{3}$ concentration analysis are not a simple linear relationship. There are common effects between different meteorological conditions. Thus, this study used multiple linear regression to analyse the association between meteorological factors and $\mathrm{O}_{3}$ concentrations. According to Table 1, the temperature in June has a very significant effect on $\mathrm{O}_{3}$ concentration, while the process of increasing $\mathrm{RH}$ in July and August reduces the $\mathrm{O}_{3}$ concentration considerably. The results are similar to those previously discused. Under high temperature, low humidity conditions will positively affect the photochemical reaction and accumulation of $\mathrm{O}_{3}$. The effect of WS on $\mathrm{O}_{3}$ in Yuncheng shows a positive correlation. When other factors remain constant and WS increases, $\mathrm{O}_{3}$ concentrations increase to some extent, which indicates that long-range transport is one of the key factors affecting $\mathrm{O}_{3}$ concentrations.

Table 1. Multiple linear regression results for $\mathrm{O}_{3}$ and meteorological factors.

\begin{tabular}{cccc}
\hline Month & Multiple Linear Regression & $\mathbf{R}^{\mathbf{2}}$ & $p$-Value \\
\hline June & $\mathrm{O}_{3}=6.399 \times \mathrm{Temp}+0.246 \times \mathrm{RH}+22.951 \times \mathrm{WS}-118.778$ & 0.562 & 0.000 \\
July & $\mathrm{O}_{3}=2.213 \times \mathrm{Temp}-0.657 \times \mathrm{RH}+17.046 \times \mathrm{WS}+61.887$ & 0.489 & 0.000 \\
August & $\mathrm{O}_{3}=1.389 \times \mathrm{Temp}-1.412 \times \mathrm{RH}+9.050 \times \mathrm{WS}+132.732$ & 0.605 & 0.000 \\
\hline
\end{tabular}

When continuous hot, dry, and soft WS weather occurs during the summer months, more attention should be paid to controlling $\mathrm{O}_{3}$ precursor emissions and long-distance transportation.

\subsection{VOCs Are Critical Precursors for Ozone Formation}

The NOx concentrations from June to August 2020 were averaged into four intervals according to their percentile to ensure that the number of hourly NOx concentrations within each concentration range was approximately the same [48]. These are the 0-25\% $\left(4-11 \mu \mathrm{g} \cdot \mathrm{m}^{-3}\right), 25-50 \%\left(11-14 \mu \mathrm{g} \cdot \mathrm{m}^{-3}\right), 50-75 \%\left(14-20 \mu \mathrm{g} \cdot \mathrm{m}^{-3}\right)$ and $75-100 \%\left(20-60 \mu \mathrm{g} \cdot \mathrm{m}^{-3}\right)$ quartiles, respectively. Figure 5 reflects the effects of different wind direction NOx concentrations on $\mathrm{O}_{3}$ in different percentile intervals. When $\mathrm{NOx}$ concentrations are below the $50 \%$ percentile, the main sources are to the north and northeast of the monitoring site. Whereas, at higher levels of NOx concentrations, the contribution from the northeast and east of the city of Yuncheng gradually dominates. The main reason for this may be that the northeastern part of the monitoring site is the main road of Yuncheng (Hongqi East Street), and traffic sources mainly influence NOx emissions.

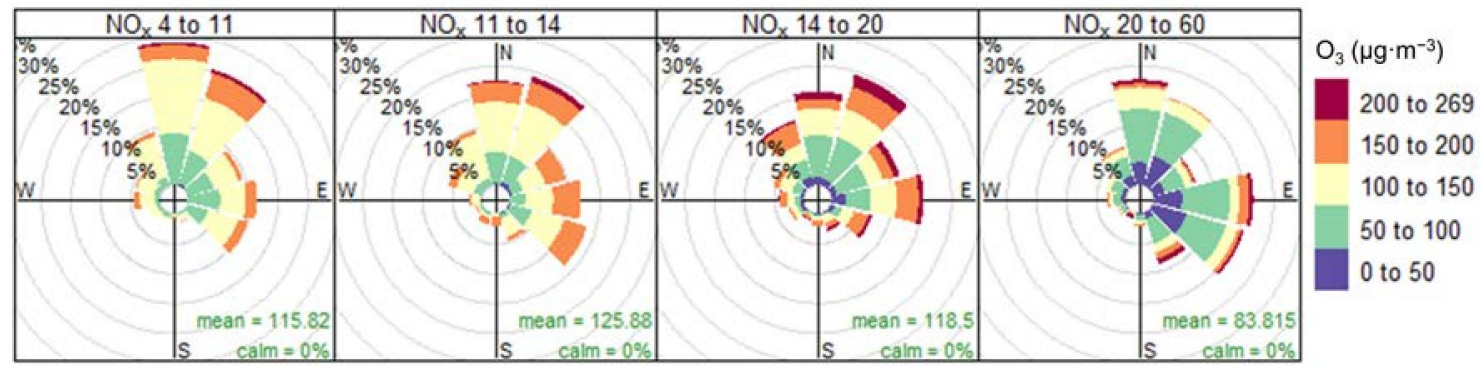

Figure 5. Effect of different percentile NOx concentrations on ozone concentrations.

In addition, Figure 5 also reveals the relationship between $\mathrm{NOx}$ and $\mathrm{O}_{3}$ concentrations. When NOx concentrations are low, most $\mathrm{O}_{3}$ concentrations are at high levels, with the most significant points lying in the $100-150 \mu \mathrm{g} \cdot \mathrm{m}^{-3}$ interval. When comparing the $\mathrm{O}_{3}$ concentrations corresponding to NOx above the 75th percentile, they are less than $100 \mu \mathrm{g} \cdot \mathrm{m}^{-3}$. Thus, NOx concentrations show a negative correlation with $\mathrm{O}_{3}$ concentrations. When the NOx concentration gradually decreased, the $\mathrm{O}_{3}$ concentration increased rather than decreased, suggesting that $\mathrm{O}_{3}$ pollution is likely in the VOCs-limited regime [49]. 
$\mathrm{O}_{3}$ production is mainly closely related to NOx and VOCs. In Figure 6, the $\mathrm{O}_{3}$ concentration was divided into three ranges of $<100 \mu \mathrm{g} \cdot \mathrm{m}^{-3}, 100-160 \mu \mathrm{g} \cdot \mathrm{m}^{-3}$ and $>160 \mu \mathrm{g} \cdot \mathrm{m}^{-3}$ to plot a three-dimensional scatter plot of $\mathrm{NOx}-\mathrm{VOCs}-\mathrm{O}_{3}$. According to the characteristic ratio method, 4 and 8 are the criteria for classifying VOCs-limited and NOx-limited regimes.
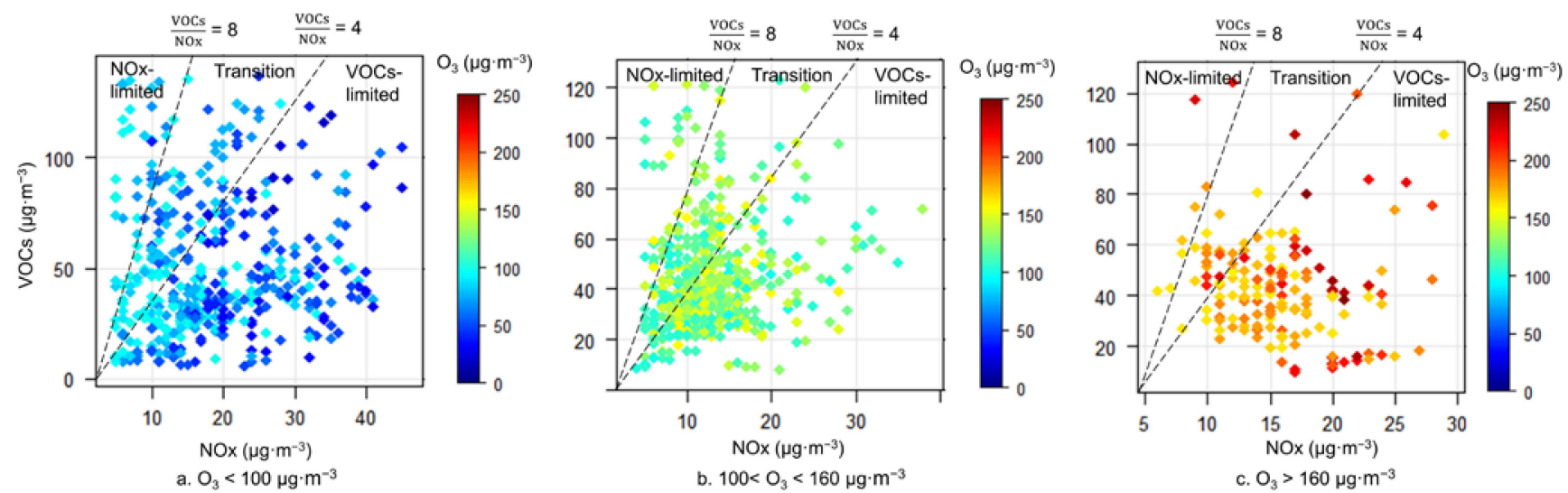

Figure 6. Three-dimensional scatter plots of VOCs-NOx-O $\mathrm{O}_{3}$ in different concentration intervals.

The main precursors of $\mathrm{O}_{3}$ in summer in Yuncheng were determined qualitatively based on the variation of $\mathrm{O}_{3}$ concentrations in the plot and their distribution locations. The study results show that under non-polluting conditions with low $\mathrm{O}_{3}$ concentrations $\left(0-100 \mu \mathrm{g} \cdot \mathrm{m}^{-3}\right)$, overall $\mathrm{O}_{3}$ concentrations are significantly lower at higher NOx concentrations. In contrast, low values of $\mathrm{O}_{3}$ concentrations are more likely to occur at lower concentrations of VOCs. In addition, according to the VOCs/NOx ratio, most of the points fall in the VOCs-limited regime and the transition zone, while some other points are in the NOx-limited regime. These results indicate that, under non-polluted conditions, VOCs are the main control factor for local $\mathrm{O}_{3}$ production, but there is still a portion of $\mathrm{O}_{3}$ in the NOx-limited regime.

When $\mathrm{O}_{3}$ concentrations were between 100 and $160 \mu \mathrm{g} \cdot \mathrm{m}^{-3}$, the number of points in the NOx-limited regime was significantly lower. Comparing the range of NOx concentrations on clean days shows that NOx concentrations range was more extensive on clean days $\left(0-40 \mu \mathrm{g} \cdot \mathrm{m}^{-3}\right)$, which further confirms the negative correlation between NOx concentration and $\mathrm{O}_{3}$ concentration. In other words, when $\mathrm{NOx}$ concentrations are high, $\mathrm{O}_{3}$ pollution is reduced.

According to the results on polluted days $\left(>160 \mu \mathrm{g} \cdot \mathrm{m}^{-3}\right)$, almost all of the points fall in the VOCs-limited regime and the transition zone. The dispersion degree of these points decreases. When controlling the NOx concentration as constant, the $\mathrm{O}_{3}$ concentration decreases with the reduction in VOCs. In contrast, maintaining constant VOCs concentration, as $\mathrm{NOx}$ concentration decreases, $\mathrm{O}_{3}$ concentration increases significantly. So, the main precursors of $\mathrm{O}_{3}$ production on polluted days are VOCs.

The mass fraction of VOCs in summer in Yuncheng was $49.98 \mu \mathrm{g} \cdot \mathrm{m}^{-3}$, where the concentration of each component was ranked as alkanes $(40 \%)>$ OVOCs $(35 \%)>$ aromatic hydrocarbons $(15 \%)>$ olefins $(8 \%)>$ alkynes $(3 \%)$. The top ten highest concentrations VOCs were acetone, acetaldehyde, ethane, propane, propionaldehyde, n-butane, ethylene, isopentane, benzene and toluene, accounting for approximately $70 \%$ of the total VOCs. As the potential for $\mathrm{O}_{3}$ formation varies between the different VOCs components, analysing only the concentration share is not an optimal method. Therefore, this study used the MIR method to calculate VOCs' ozone formation potential (OFP) and assess VOC components' ability to generate $\mathrm{O}_{3}$ [50]. According to the OFP results, the rank of different kinds of VOCs's OFP is as follows: OVOCs $(45 \%)>$ olefins $(25 \%)>$ aromatic hydrocarbons $(18 \%)>$ alkanes $(11 \%)>$ alkynes $(1 \%)$. The most significant OFP contributing species were acetaldehyde, propionaldehyde, ethylene, isoprene, toluene, $\mathrm{m} / \mathrm{p}$-xylene, propylene, 
isopentane, o-xylene and n-butane. Thus, controlling the emissions of the above species is important to mitigate summer $\mathrm{O}_{3}$ pollution in the urban area of Yuncheng.

Overall, in terms of the current $\mathrm{O}_{3}$ pollution situation in Yuncheng, VOCs emission control is more critical to reduce summer $\mathrm{O}_{3}$ concentration. However, it is worth noting that, as air quality is optimised and $\mathrm{O}_{3}$ pollution will gradually decline, the precursor control situation will move progressively towards the NOx-limited regime. In the current $\mathrm{O}_{3}$ control process, the control of VOC concentrations will have a meaningful impact. However, in the future, it will become more and more significant when discussing $\mathrm{O}_{3}$ pollution control.

\subsection{Interregional Transportation}

\subsubsection{Transmission Trajectory Characteristics}

This study used the Hysplit model to calculate every 6-h backward trajectory from 1 June to 31 August 2020. This method intends to analyse the characteristics of atmospheric $\mathrm{O}_{3}$ transport pathways in Yuncheng $\left(110.98^{\circ} \mathrm{E}, 35.02^{\circ} \mathrm{N}\right)$ during summer. The backward trajectory air masses were clustered into four classes by the TSV method (Figure 7). Daily hourly concentrations of $\mathrm{O}_{3}$ were statistically analysed in conjunction with air mass trajectories to characterise the pollutant concentrations quantitatively in each airflow trajectory (Table 2).

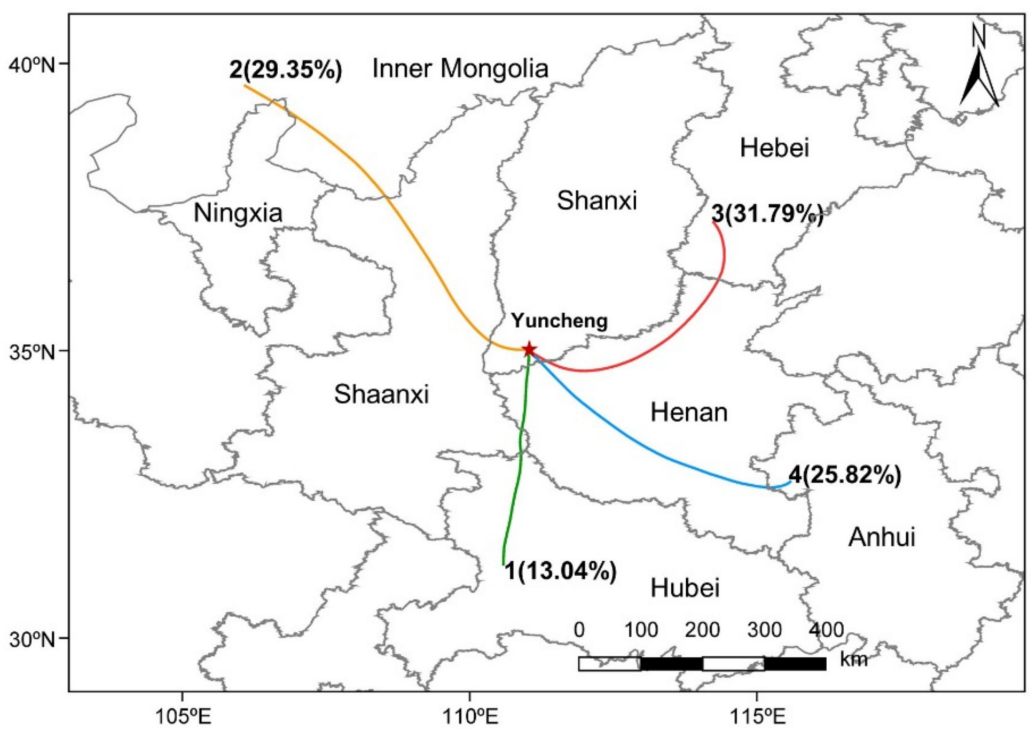

Figure 7. Cluster distribution of backward trajectories of ozone in summer Yuncheng. The green, yellow, red, and blue lines represent clustered trajectories of air masses from different directions.

Table 2. Results of the statistical analysis of the trajectories and the probability of occurrence and corresponding ozone concentrations in summer.

\begin{tabular}{|c|c|c|c|c|c|}
\hline \multirow{2}{*}{ No. } & \multirow{2}{*}{ Route Area } & \multicolumn{2}{|c|}{ All Trajectories } & \multicolumn{2}{|c|}{ Contamination Trajectory } \\
\hline & & Probability $/ \%$ & $\rho\left(\mathrm{O}_{3}\right) / \mu \mathrm{g} \cdot \mathrm{m}^{-3}$ & Seasonal Share $1 / \%$ & $\rho\left(\mathrm{O}_{3}\right) / \mu \mathrm{g} \cdot \mathrm{m}^{-3}$ \\
\hline 1 & Western Hubei and Western Henan & 13.04 & 97.43 & 6.45 & 168.50 \\
\hline 2 & Southern Inner Mongolia and northern Shaanxi & 29.35 & 100.03 & 25.81 & 169.13 \\
\hline 3 & Southern Hebei and northern Henan & 31.79 & 104.93 & 23.66 & 170.73 \\
\hline 4 & Northwestern Anhui and most of Henan & 25.82 & 134.89 & 44.09 & 173.20 \\
\hline
\end{tabular}

${ }^{1}$ Major pollution trajectories in bold ( $>25 \%$ seasonal share).

According to Figure 6 and Table 1, track $3^{\prime}$ s probability is the highest (31.79\%), starting from the south of Hebei, then through the north of Henan to Yuncheng. However, the average $\rho\left(\mathrm{O}_{3}\right)$ and contamination trajectory share are not the highest, around $104.93 \mu \mathrm{g} \cdot \mathrm{m}^{-3}$ and $23.66 \%$, respectively. The highest probability of pollution track (track 4 ) from north- 
western Anhui, arriving at Yuncheng via most of Henan, can be $44.09 \%$. The mean and contaminated trajectory concentrations were $134.89 \mu \mathrm{g} \cdot \mathrm{m}^{-3}$ and $173.20 \mu \mathrm{g} \cdot \mathrm{m}^{-3}$, which are the highest of all tracks. Track 2 from southern Inner Mongolia, across northern Shaanxi to Yuncheng, has the second probability of occurrence after track 3 . However, its pollution concentration is low, probably due to its long transmission distance and fast-moving speed, which is not conducive to the accumulation of pollutants. Track 1 from western Hubei has the lowest probability for all trajectories and contaminated paths, at $13.04 \%$ and $6.45 \%$, and the lowest pollution concentrations, at $97.43 \mu \mathrm{g} \cdot \mathrm{m}^{-3}$ and $168.50 \mu \mathrm{g} \cdot \mathrm{m}^{-3}$.

\subsubsection{Long-Range Transport Sources of Ozone Pollution}

Based on the Section 3.4.1 analysis, this research used Trajstat software to do a potential source analysis (WPSCF) of $\mathrm{O}_{3}$ in Yuncheng (Figure 8a). Areas with a WPSCF value greater than 0.5 were the most significant potential source areas subject to point contamination. In Figure $8 \mathrm{a}$, the primary potential sources of $\mathrm{O}_{3}$ pollution in summer are in the southeast. The WPSCF results greater than 0.5 are mainly in central and southern Henan, northwestern Anhui and northern Hubei. The regions calculated 0.4 to 0.5 are mainly Shaanxi north, central and west Henan, and Hubei north. As most of the areas with high WPSCF values are in the southeast of Yuncheng, this may be related to the prevailing southeasterly winds aloft during the summer months in Yuncheng.
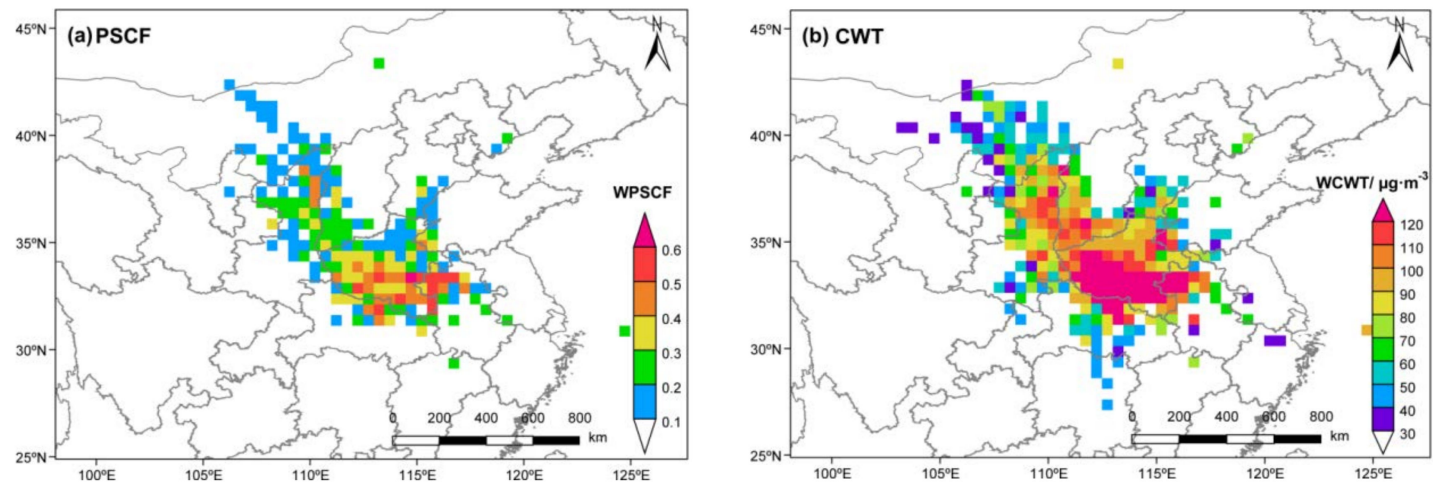

Figure 8. (a): Distribution of potential source contribution of ozone in summer in Yuncheng (WPSCF). (b): Trajectory distribution of ozone concentration weights in Yuncheng (WCWT).

To further explore the degree of pollution contribution of source areas to $\mathrm{O}_{3}$ in Yuncheng City and to verify the results of the WPSCF analysis, the WCWT method was carried out (Figure $8 \mathrm{~b}$ ). Larger WCWT values represent a more significant pollution contribution to the receiving point, and this study defined $100 \mu \mathrm{g} \cdot \mathrm{m}^{-3}$ as major contributing areas. The results of the WCWT analysis are similar to the WPSCF. Regions with WCWT values greater than $120 \mu \mathrm{g} \cdot \mathrm{m}^{-3}$ are mainly in central Henan and northern Hubei, and northwestern Anhui's border. Besides, in north Shaanxi, southwestern Shanxi and southwestern Shandong, which also have sporadic areas greater than $120 \mu \mathrm{g} \cdot \mathrm{m}^{-3}$. The WCWT values of $100-120 \mu \mathrm{g} \cdot \mathrm{m}^{-3}$ were mainly in northern Shaanxi, southwestern Shanxi, and northern Hebei. Some high WCWT also exist in north Henan, southern Inner Mongolia, southern Hebei, southwestern Shandong, north of Hubei and northwestern Anhui.

The main potential source areas for summer $\mathrm{O}_{3}$ in Yuncheng are in the southeast, mainly in the central and southern part of Henan province and the northwestern part of Anhui province. In addition, northern Shaanxi, northern Hubei and southwestern Shandong also influence summer $\mathrm{O}_{3}$ pollution.

\section{Conclusions}

Compared to 2018 and 2019, the summer of 2020 showed more persistent $\mathrm{O}_{3}$ pollution in Yuncheng. In particular, the $\mathrm{O}_{3}$ concentration in June shows a continuity of multi-hour pollution and severity of contamination, even higher than $265 \mu \mathrm{g} \cdot \mathrm{m}^{-3}$. Due to photochem- 
ical reaction conditions, the seasonal characteristics of $\mathrm{O}_{3}$ pollution in Yuncheng in 2020 are summer $>$ autumn $>$ spring $>$ winter. In summer, the peak pollution concentrations are highest in June $\left(155 \mu \mathrm{g} \cdot \mathrm{m}^{-3}\right)$, significantly higher than in July $\left(145 \mu \mathrm{g} \cdot \mathrm{m}^{-3}\right)$ and August $\left(120 \mu \mathrm{g} \cdot \mathrm{m}^{-3}\right)$. The NOx and VOC concentrations vary opposite to $\mathrm{O}_{3}$ because their concentrations are influenced by the emission conditions and photochemical reactions degree. The $\mathrm{O}_{3}$ pollution scenario for 2020 cannot occur without meteorological factors, local generation, and transmission from air masses.

According to the influence of meteorological factors on $\mathrm{O}_{3}$ concentrations, there is a positive correlation between temperature and $\mathrm{O}_{3}$ concentrations. A decreasing trend in $\mathrm{O}_{3}$ concentration occurs gradually when the $\mathrm{RH}$ is more significant than $60 \%$. Afternoon peak temperatures in June 2020 were above $30^{\circ} \mathrm{C}$, significantly higher than in July $\left(29^{\circ} \mathrm{C}\right)$ and August $\left(28^{\circ} \mathrm{C}\right)$. At the same time, the RH was higher than $65 \%$ in July and August, which contributes to afternoon temperatures staying at lower levels. The low temperatures and high humidity (cloudy weather) in July and August indicate that the intensity of solar radiation is weaker, so $\mathrm{O}_{3}$ concentrations are significantly lower than in June. According to the multiple linear regression results, the wind speed was positively correlated with $\mathrm{O}_{3}$ concentrations in Yuncheng from June to August with correlation coefficients of 22.951, 17.046 and 9.050, respectively. Higher $\mathrm{O}_{3}$ concentrations may occur when higher wind speeds arise, suggesting that $\mathrm{O}_{3}$ concentrations from regional transport need to be noted.

The local formation of $\mathrm{O}_{3}$ in Yuncheng is inseparable from the emission of VOCs. $\mathrm{O}_{3}$ concentration increased when NOx concentration decreased suggests that the VOCs concentration control may be more effective in controlling local $\mathrm{O}_{3}$ pollution. When $\mathrm{O}_{3}$ concentrations are high, the VOCs/NOx ratio is less than 8 , indicating that $\mathrm{O}_{3}$ generation is sensitive to VOCs. When $\mathrm{O}_{3}$ concentrations are low, VOCs/NOx ratio move towards the transition zone and the NOx-limited regime, meaning that when the $\mathrm{O}_{3}$ pollution level is reduced, the pollution of $\mathrm{O}_{3}$ by NOx emissions should not be underestimated. According to the current pollution situation in Yuncheng, VOCs are the main control factor for controlling $\mathrm{O}_{3}$ pollution. The most significant OFP contributing species were acetaldehyde, propionaldehyde, ethylene, isoprene, toluene, $\mathrm{m} / \mathrm{p}$-xylene, propylene, isopentane, o-xylene and n-butane. Therefore, the emission control of the top ten OFP VOCs mentioned above will be crucial to managing $\mathrm{O}_{3}$ pollution.

The results of the transport trajectories analysis show that southeast-oriented air masses are the main track affecting $\mathrm{O}_{3}$ pollution in Yuncheng in summer 2020, with a seasonal share of $44.09 \%$ and a pollution concentration as high as $173.20 \mu \mathrm{g} \cdot \mathrm{m}^{-3}$. The WPSCF and WCWT analyses indicate that the main potential source areas of $\mathrm{O}_{3}$ are mainly in central and southern Henan and northwestern Anhui. In addition, northern Shaanxi, northern Hubei, and southwestern Shandong also influence $\mathrm{O}_{3}$ pollution in the summer Yuncheng.

Author Contributions: Conceptualisation, C.Z.; methodology, C.Z. and Y.W.; software, C.Z. and Y.W.; validation, C.Z.; formal analysis, C.Z.; investigation, C.Z.; resources, S.L., X.W. and W.Z.; data curation, C.Z.; writing-original draft preparation, C.Z. and Y.W.; writing-review and editing, C.Z.; visualisation, and Y.W.; supervision, C.Q. and X.L.; project administration, Q.Z. All authors have read and agreed to the published version of the manuscript.

Funding: This research was funded by National Key R\&D Programmes (SQ2019YFC020023) and Research Project on the Causes and Control of Heavy Air Pollution (DQGG202110).

Acknowledgments: This study is grateful to all the platforms that provided software support and to the projects that were financially supported (National Key R\&D Programmes (SQ2019YFC020023) and Research Project on the Causes and Control of Heavy Air Pollution (DQGG202110)).

Conflicts of Interest: The authors declare no conflict of interest.

\section{References}

1. Yue, H.; He, C.; Huang, Q.; Yin, D.; Bryan, B.A. Stronger policy required to substantially reduce deaths from $\mathrm{PM}_{2.5}$ pollution in China. Nat. Commun. 2020, 11, 1462. [CrossRef] [PubMed] 
2. Xiao, Q.; Geng, G.; Liang, F.; Wang, X.; Lv, Z.; Lei, Y.; He, K. Changes in spatial patterns of PM2.5 pollution in China 2000-2018: Impact of clean air policies. Environ. Int. 2020, 141, 105776. [CrossRef] [PubMed]

3. LIu, Y.; Wang, T. Worsening urban ozone pollution in China from 2013 to 2017-Part 2: The effects of emission changes and implications for multi-pollutant control. Atmos. Chem. Phys. 2020, 20, 6323-6337. [CrossRef]

4. Li, K.; Jacob, D.J.; Shen, L.; Lu, X.; De Smedt, I.; Liao, H. Increases in surface ozone pollution in China from 2013 to 2019 Anthropogenic and meteorological influences. Atmos. Chem. Phys. 2020, 20, 11423-11433. [CrossRef]

5. Wang, Y.; Gao, W.; Wang, S.; Song, T.; Gong, Z.; Ji, D.; Zhang, Y. Contrasting trends of PM2. 5 and surface-ozone concentrations in China from 2013 to 2017. Natl. Sci. Rev. 2020, 7, 1331-1339. [CrossRef]

6. Li, G.; Bei, N.; Cao, J.; Wu, J.; Long, X.; Feng, T.; Tie, X. Widespread and persistent ozone pollution in eastern China during the non-winter season of 2015: Observations and source attributions. Atmos. Chem. Phys. 2017, 17, 2759-2774. [CrossRef]

7. Akimoto, H.; Izuta, T.; Ueda, H. Tropospheric Ozone: A Growing Threat; Acid Deposition and Oxidant Research Center: Niigata, Japan, 2006; Volume 26.

8. Young, P.J.; Archibald, A.T.; Bowman, K.W.; Lamarque, J.F.; Naik, V.; Stevenson, D.S.; Zeng, G. Pre-industrial to end 21st century projections of tropospheric ozone from the Atmospheric Chemistry and Climate Model Intercomparison Project (ACCMIP). Atmos. Chem. Phys. 2013, 13, 2063-2090. [CrossRef]

9. Wang, M.; Zheng, Y.F.; Liu, Y.J.; Li, Q.P.; Ding, Y.H. Characteristics of ozone and its relationship with meteorological factors in Beijing-Tianjin-Hebei Region. China Environ. Sci. 2019, 39, 2689-2698.

10. An, J.; Zou, J.; Wang, J.; Lin, X.; Zhu, B. Differences in ozone photochemical characteristics between the megacity Nanjing and its suburban surroundings, Yangtze River Delta, China. Environ. Sci. Pollut. Res. 2015, 22, 19607-19617. [CrossRef]

11. Wang, X.D.; Yin, S.S.; Yang, J.; Yuan, M.H.; Zhang, R.Q.; Li, Y.S.; Lu, X. Characteristics, Meteorological Influences, and Transport Source of Ozone Pollution in Zhengzhou City. Huan Jing ke Xue Huanjing Kexue 2021, 42, 604-615.

12. Ou, S.J.; Wei, W.; Wang, X.Q.; Yao, S.; Zhou, Z.B.; Guan, P.B.; Yao, S.Y. Pollution Characteristics and Sensitivity of Surface Ozone in a Typical Heavy-Industry City of the North China Plain in Summer. Huan Jing ke Xue Huanjing Kexue 2020, 41, 3085-3094.

13. Wang, Q.L.; Dong, M.L.; Li, S.J.; Wu, C.Z.; Wang, G.; Chen, B.X.; Ye, R.M. Characteristics of ozone pollution distribution and source apportionment in Zhoushan. Huan jing ke xue Huanjing kexue 2019, 40, 1143-11451.

14. Liu, B.; Liang, D.; Yang, J.; Dai, Q.; Bi, X.; Feng, Y.; Xu, H. Characterization and source apportionment of volatile organic compounds based on 1-year of observational data in Tianjin, China. Environ. Pollut. 2016, 218, 757-769. [CrossRef]

15. Xue, L.; Xu, S.; Sun, M.; Meng, H.; Wang, J.; Zhang, Y.; Liu, Y. Effect of Meteorological Factors and Precursors on the Change of Ambient Air Ozone Concentrations in Qingdao. Environ. Monit. China 2017, 33, 179-185.

16. Teng, P. Study on Characteristics of Atmospheric VOC Pollution and Its Contribution to Ozone Formation in Jinan; Qilu University of Technology: Jinan, China, 2020.

17. Wang, Y.; Zhang, Q.; Wen, X.; Dou, N.; Zhao, W.; Luo, S.; Chen, Z.; Qu, C. Spatiotemporal Distribution and Seasonal Characteristics of Regional Transport of $\mathrm{PM}_{2.5}$ in Yuncheng City. Environ. Sci. 2021, 1-16. [CrossRef]

18. Li, Y.Y.; Li, J.; Zeng, S.L.; Zhu, L.L.; Wang, W. Analysis of Atmospheric Particulates in the Eastern Fenwei Plain in 2017. Environ. Sci. Res. 2020, 33, 63-72.

19. Zhang, H. Characteristics of Air Pollution and Source Analysis of Particulate Matter in Xi'an; Xi'an University of Architecture and Technology: Xi'an, China, 2020.

20. Xu, J.; Ma, J.Z.; Zhang, X.L.; Xu, X.B.; Xu, X.F.; Lin, W.L.; Ma, Z.Q. Measurements of ozone and its precursors in Beijing during summertime: Impact of urban plumes on ozone pollution in downwind rural areas. Atmos. Chem. Phys. 2011, 11, 12241-12252. [CrossRef]

21. Wang, Y.; Du, H.; Xu, Y.; Lu, D.; Wang, X.; Guo, Z. Temporal and spatial variation relationship and influence factors on surface urban heat island and ozone pollution in the Yangtze River Delta, China. Sci. Total Environ. 2018, 631, 921-933. [CrossRef]

22. He, Z.; Wang, X.; Ling, Z.; Zhao, J.; Guo, H.; Shao, M.; Wang, Z. Contributions of different anthropogenic volatile organic compound sources to ozone formation at a receptor site in the Pearl River Delta region and its policy implications. Atmos. Chem. Phys. 2019, 19, 8801-8816. [CrossRef]

23. Hao, C.F.; Jia, Y.W.; Gong, J.G.; Peng, H. Analysis on characteristics and rules of climate change of Haihe River Basin in recent 50 years. J. China Inst. Water Resour. Hydropower Res. 2010, 8, 39-43.

24. MEE. Technical Regulation for Selection of Ambient Air Quality Monitoring Stations (HJ 664-2013). Ministry of Ecology and Environment of the People's Republic of China. Available online: https://www.mee.gov.cn/ywgz/fgbz/bz/bzwb/jcffbz/2013 09/t20130925_260810.htm (accessed on 1 October 2013).

25. Villena, G.; Bejan, I.; Kurtenbach, R.; Wiesen, P.; Kleffmann, J. Interferences of commercial $\mathrm{NO}_{2}$ instruments in the urban atmosphere and in a smog chamber. Atmos. Meas. Tech. 2012, 5, 149-159. [CrossRef]

26. Draxler, R.; Stunder, B.; Rolph, G.; Stein, A.; Taylor, A. HYSPLIT4 User's Guide Version 4-Last Revision: February 2016; HYSPLIT Air Resources Laboratory: College Park, MD, USA, 2016.

27. Wang, Y.; Zhang, X.; Draxler, R.R. TrajStat: GIS-based software that uses various trajectory statistical analysis methods to identify potential sources from long-term air pollution measurement data. Environ. Model. Softw. 2009, 24, 938-939. [CrossRef]

28. Wang, F.; Chen, D.S.; Cheng, S.Y.; Li, M.J. Impacts of air pollutant transport based on air trajectory clustering. Res. Environ. Sci. 2009, 22, 637-642.

29. Draxler, R.R.; Hess, G. An overview of the HYSPLIT_4 modelling system for trajectories. Aust. Meteorol. Mag. 1998, 47, 295-308. 
30. Fleming, Z.L.; Monks, P.S.; Manning, A.J. Untangling the influence of air-mass history in interpreting observed atmospheric composition. Atmos. Res. 2012, 104, 1-39. [CrossRef]

31. Begum, B.A.; Kim, E.; Jeong, C.H.; Lee, D.W.; Hopke, P.K. Evaluation of the potential source contribution function using the 2002 Quebec forest fire episode. Atmos. Environ. 2005, 39, 3719-3724. [CrossRef]

32. Zhang, L.; Shen, F.; Gao, J.; Cui, S.; Yue, H.; Wang, J.; Ge, X. Characteristics and potential sources of black carbon particles in suburban Nanjing, China. Atmos. Pollut. Res. 2020, 11, 981-991. [CrossRef]

33. Polissar, A.V.; Hopke, P.K.; Harris, J.M. Source regions for atmospheric aerosol measured at Barrow, Alaska. Environ. Sci. Technol. 2001, 35, 4214-4226. [CrossRef]

34. Hsu, Y.-K.; Holsen, T.M.; Hopke, P.K. Comparison of hybrid receptor models to locate PCB sources in Chicago. Atmos. Environ. 2003, 37, 545-562. [CrossRef]

35. Seibert, P.; Kromp-Kolb, H.; Baltensperger, U.; Jost, D.T.; Schwikowski, M. Trajectory analysis of high-alpine air pollution data. In Air Pollution Modeling and Its Application X; Springer: New York, NY, USA, 1994; pp. 595-596.

36. Reizer, M.; Orza, J.A. Identification of PM10 air pollution origins at a rural background site. E3S Web Conf. 2018, 28, 01031. [CrossRef]

37. Dvorská, A.; Lammel, G.; Holoubek, I. Recent trends of persistent organic pollutants in air in central Europe-Air monitoring in combination with air mass trajectory statistics as a tool to study the effectivity of regional chemical policy. Atmos. Environ. 2009, 43, 1280-1287. [CrossRef]

38. MEE. Ambient Air Quality Standards (GB 3095-2012) [Z]//China Moeaeotpsro. Available online: https://www.mee.gov.cn/ ywgz/fgbz/bz/bzwb/dqhjbh/dqhjzlbz/201203/t20120302_224165.shtml (accessed on 1 January 2016).

39. Zhao, S.; Yin, D.; Yu, Y.; Kang, S.; Qin, D.; Dong, L. PM 2.5 and $\mathrm{O}_{3}$ pollution during 2015-2019 over 367 Chinese cities: Spatiotemporal variations, meteorological and topographical impacts. Environ. Pollut. 2020, 264, 114694. [CrossRef] [PubMed]

40. IZuta, T. Air Pollution Impacts on Plants in East Asia; Springer: New York, NY, USA, 2017.

41. Bais, A.F.; Bernhard, G.; McKenzie, R.L.; Aucamp, P.J.; Young, P.J.; Ilyas, M.; Deushi, M. Ozone-climate interactions and effects on solar ultraviolet radiation. Photochem. Photobiol. Sci. 2019, 18, 602-640. [CrossRef] [PubMed]

42. Liu, Y.; Wang, H.; Jing, S.; Peng, Y.; Gao, Y.; Yan, R.; Huang, C. Strong regional transport of volatile organic compounds (VOCs) during wintertime in Shanghai megacity of China. Atmos. Environ. 2021, 244, 117940. [CrossRef]

43. Xiong, C.; Wang, N.; Zhou, L.; Yang, F.; Qiu, Y.; Chen, J.; Li, J. Component characteristics and source apportionment of volatile organic compounds during summer and winter in downtown Chengdu, southwest China. Atmos. Environ. 2021, $258,118485$. [CrossRef]

44. Kaser, L.; Peron, A.; Graus, M.; Striednig, M.; Wohlfahrt, G.; Juráň, S.; Karl, T. Interannual Variability of BVOC Emissions in an Alpine City. Atmos. Chem. Phys. Discuss 2021, 2021, 1-26.

45. Juráň, S.; Šigut, L.; Holub, P.; Fares, S.; Klem, K.; Grace, J.; Urban, O. Ozone flux and ozone deposition in a mountain spruce forest are modulated by sky conditions. Sci. Total Environ. 2019, 672, 296-304. [CrossRef]

46. Dueñas, C.; Fernández, M.C.; Cañete, S.; Carretero, J.; Liger, E. Assessment of ozone variations and meteorological effects in an urban area in the Mediterranean Coast. Sci. Total Environ. 2002, 299, 97-113. [CrossRef]

47. Wang, Z.S.; Li, Y.T.; Chen, T.; Zhang, D.W.; Sun, F.; Sun, R.W.; Pan, L.B. Temporal and spatial distribution characteristics of ozone in Beijing. Huan jing ke xue Huanjing kexue 2014, 35, 4446-4453.

48. Carslaw, D.C. The Openair Book Tools for Air Quality Data Analysis. Available online: https://bookdown.org/david_carslaw/ openair / (accessed on 10 November 2020).

49. Yang, Y.; Zhao, Y.; Zhang, L.; Zhang, J.; Huang, X.; Zhao, X.; Lu, Y. Improvement of the satellite-derived $\mathrm{NO}_{x}$ emissions on air quality modeling and its effect on ozone and secondary inorganic aerosol formation in the Yangtze River Delta, China. Atmos. Chem. Phys. 2021, 21, 1191-1209. [CrossRef]

50. Carter, W.P. Development of a condensed SAPRC-07 chemical mechanism. Atmos. Environ. 2010, 44, 5336-5345. [CrossRef] 